[Besley, T. (2002). Over Forty Years of Guidance Counselling: Specialist Teachers in New Zealand Secondary Schools 1959-2001. New Zealand Annual Review of Education, 11, 275-302]

\section{Over Forty Years of Guidance Counselling: Specialist Teachers in New Zealand Secondary Schools 1959-2001}

\section{TINA BESLEY}

\section{Abstract:}

This article provides a brief overview of forty years of guidance counselling in New Zealand secondary schools, at a time that has seen New Zealand move from a welfare state to a neoliberal one. By focussing primarily on official policy and its impact on the place of guidance counsellors, it identifies five phases in the development of this small, but important section of semi-visible "specialist teachers". The article also provides a broad picture of the socio-politicalhistorical contexts that supported the emergence of assisted pilot guidance counsellor schemes at the end of 1959, and their development so that there were permanent places in all secondary schools by 1988. It also indicates some of the threats in the neoliberal policy environment of the 1990s.

ince 1959 the social and policy context in which school counselling way in the late 1980s and 1990s to the inroads of neoliberal managerialist ideology, rather than being largely set by Department of Education policy and influenced by a range of official reports, since 1996 there has been considerable flexibility in how schools conduct their guidance function (Department of Education, 1944, 1962, 1969, 1971, 1977, 1988; Kelsey, 1993, 1995; Mazengarb Report, 1954; Ministry of Education, 1988a, 1988b, 1993, 1995, 1997, 1999a, 1999b; Peters, 2001). Even the terminology has tended to change over time with the term "guidance" being largely (but unofficially) dropped in many schools because it has connotations of directiveness that no longer reflect how
276 Tina Besley

the profession works. Yet today almost all New Zealand secondary schools, state and private, continue to have at least one guidance counsellor.

A guidance counsellor usually heads a guidance department or network comprising personnel, such as guidance teachers, careers advisors, transition teachers, youth workers and sometimes social workers, and what is now commonly called student support services. Some schools have guidance teachers whose role involves counselling, and teaching health education. They are often undergoing training to become fully-fledged guidance counsellors. In many schools, especially large urban schools, the original three-part role of educational, vocational and emotional guidance has generally been split between other staff members: for example, deans undertake educational guidance (and administration and discipline for their year cohort), whilst form teachers and senior staff provide general pastoral care and discipline. Counsellors do not administer discipline, but may assist students in trouble with the disciplinary system, advocating for them at disciplinary hearings, conducting mediation and conflict-resolution procedures, re-integrating them back into school at the end of a period of exclusion, or helping them to enrol at another school or alternative education venue. Careers advisors and transition teachers specialise in careers guidance and job-work transitions and often teach health education (as do some physical education staff, guidance teachers and school counsellors). Learning support or special needs departments and Resource Teachers Learning and Behaviour(RTLBs) deal with learning difficulties and conduct some diagnostic testing. Today, therefore, the focus for many school counsellors is primarily on personal counselling for students as a means of removing barriers to learning, along with assisting schools fulfil all the National Educational Goals and National Administrative Guidelines (Ministry of Education, 1993).

\section{Beginnings - The Social Context}

The first vocational guidance programmes appeared in the late $1800 \mathrm{~s}$ in both the USA and New Zealand. During the 20th century, a combination of factors - economic and social conditions; political decisions; community involvement; and the influence of psychology in university departments of education - all resulted in the establishment of a range of guidance services in New Zealand. These included: Vocational Guidance Service (1938), Visiting Teachers (1943), Psychological Service (1948), Child Guidance Clinics (1951), and lastly, 
School Guidance Counsellors (1959). All but the child guidance clinics, which were under the Department of Health, were in the control of the Department of Education. Early in the 20th century, the founding professors of education at each university college displayed enormous interest and support for lecturing, researching and applying psychological theories and testing. This played a major role in the setting up of guidance clinics, which were subsequently expanded by the state Department of Education (Besley, 2000). Furthermore, in the late 1920s and early 1930s the major technical high schools, which had a more humanitarian and liberal outlook than state and private single sex high schools, were establishing careers advisors - a position that became established in all schools in 1948 (Winterbourn, 1974). During World War II, the visiting teacher system was set up using social workers ${ }^{1}$ who were qualified teachers. They were placed in clusters of primary and intermediate schools to deal with truancy and children's social problems, by working in partnership with, and maintaining liaison between school, home and outside agencies (1974). After becoming part of the Specialist Education Service, visiting teachers were disestablished in 1997.

The post-war social context, the rise of psychological disciplines, and several "moral panics" as youth cultures emerged, led to guidance counselling systems being set up in USA, UK and New Zealand schools in the late 1950s (Cohen, 1980; Hall \& Jefferson, 1976; Thompson, 1998; Winterbourn, 1974). These had a much broader and more developmental focus than vocational guidance. During and immediately after World War II, family life had suffered in these countries. There was considerable concern about a rise in juvenile delinquency, because the military and economic activities of parents often meant that the guidance and discipline of children and adolescents was sporadic or even non-existent (Winterbourn, 1974; Yska, 1993). After the traumas of two world wars, Western nations became fearful of communist take-overs and the possibility of nuclear annihilation. Despite youth freedoms being rapidly curtailed as mothers returned into the home and fathers returned into jobs vacated by women after the war, "social workers, teachers and others became increasingly concerned about problems of juvenile delinquency and moral standards, truancy, and other social problems" (Winterbourn 1974, p. 78). Furthermore some texts linked juvenile immorality and delinquency with attachment loss and maternal deprivation (Wylie, 1942; Bowlby, 1947, 1953; Molloy, 1993). The influence of popular music (especially rock ' $\mathrm{n}$ ' roll), and of drugs led to widespread fears of these leading to youth promiscuity, anti-social behaviour and addiction. Many adults were appalled at the appearance and overt sexuality of popular stars and singers (e.g., Marlon Brando, James Dean, Johnnie Rae, Johnny Devlin and Max Merritt) and especially by Elvis Presley's famous hip swivel and pelvic thrusts. The 1950s media often depicted youth as rebellious, bad mannered, disrespectful, impolite, and, at worst, as delinquent. Many of society's moral agents, including the churches, believed they were facing youthful rebellion. A popular perception was that New Zealand was following a similar path to America and Britain and that what happened there would eventually arrive here (Yska, 1993). To a certain extent, New Zealand adopted imported fears and concerns about the "youth problem" and delinquency amid a reaction to post-war incursions of American pop culture, in a society that still largely regarded Britain as "home", and consequently considered British culture to be superior to the American model. What is now seen as the emergence of a distinctive youth culture and subcultures began to appear in the 1940s-1950s in American high schools. This revolved mostly around music, clothes, dating, cars and particular verbal codes. At the time, this was largely greeted by adult alarm, and often treated as a "moral panic" about the moral constitution of youth, social disorder, and threats to the accepted cultural norms and practices (Hall \& Jefferson, 1976; Hebdige, 1979; McRobbie, 1991; Manning, 1958; Shuker et al., 1990; Soler, 1988, 1989; Yska, 1993).

Public concern in the form of a "moral panic" emerged in New Zealand in the mid-1950s (Molloy, 1993; Shuker et al., 1990; Soler, 1988, 1989). Ten years after visiting teachers were placed in primary and intermediate schools, the theme of social, economic, political and moral problems regarding youth re-emerged. Secondary schools expressed concern about discipline problems and juvenile delinquency. In 1952 there was some sexual misbehaviour amongst young people in the Hutt Valley, and police, welfare officers and Auckland headmasters reported "an accumulation of sordid happenings occurring within a short space of time" (Mazengarb Report, 1954, p. 13). In June 1954, newspapers ${ }^{2}$ reported the arrest of 57 young people (41 boys, 16 girls, some aged 13-15 years) in the Hutt Valley for sexual misconduct (carnal knowledge and indecent assault which apparently occurred in private homes and picture theatres) after a 15 year old girl admitted to police that to be popular she had repeatedly had sex with members of a "Milk Bar Gang" 
(pp. 11-12). As a result, in 1954 the government set up a Special Committee on Moral Delinquency in Children and Adolescents that produced the Mazengarb Report. This focussed on the need to control the behaviour of youth, (especially "teddy boys", "milk-bar cowboys", "bodgies" and "widgies") and their parents, and highlighted the perceived negative effects of American cultural influences (e.g., comics, pulp fiction and rock ' $n$ ' roll), and the apparent decay in morality and the lack of resources in new suburban areas (Besley, 2000). About the same time, the national press also reported on sensational murders by teenagers - the Parker-Hulme bashing by supposedly lesbian teenage girls in Christchurch in 1954, followed by the "Jukebox" shooting in Auckland in 1955 (Yska, 1993). Hence, the scene was set for the development of social guidance and counselling in schools that shape, constitute and control the morality of youth. These form what Foucault (1988a) describes as "technologies of domination" and "technologies of the self" where "technology" is the actual practice of power that involves "the government of individuals, the government of the souls, the government of the self by the self, the government of families, the government of children, and so on" (Foucault, 1984, p. 256). Foucault's discussion (1988a, 1988b, 1989) links political rationality and the emergence of the social sciences, and his work on morality provides some perspectives on why our society seems so concerned about youth morality and in providing guidance in such matters. To a certain extent these technologies were about moral development, but they were also about social control and the assertion of adult authority in a manner that reflected notions of mental hygiene ${ }^{3}$ in the early post-war years (Besley, 2002a).

\section{Phase 1: The 1950s-1964: Guidance Counsellor Pilot Programmes}

It was particularly the "moral panic" embodied in the Mazengarb Report (1954) along with the rapid expansion of secondary school rolls that set the scene for school counselling to develop in New Zealand in the late 1950s. The Report recommended more visiting teachers for primary schools (Auckland two, Wellington and Christchurch one each), but surprisingly, considering its somewhat directive tone, it left the Department of Education to "consider what type of officer is best suited to help with problem pupils in post-primary schools" (Mazengarb Report, 1954, p. 68). Dr C E. Beeby, Director-General of Education, in his Annual Report to the Department of Education, 1955, took the community to task for its unrealistic expectations of the moral influence schools could or should have on their students. He believed that schools could not be expected to inculcate moral standards that were very different from those commonly observed in the community as a whole (Alcorn, 1999). Beeby's commitment to psychology and to guidance was longstanding, but he was not directly instrumental in the pioneering moves that set up guidance counselling (Small, 2000). His understanding of education in liberal and progressive terms arguably set the overall climate that enabled guidance counselling to emerge. He promoted the view exhibited in the Thomas Report that education should be a liberating, enjoyable, realistic experience that fitted the majority of the population culturally and economically for the world they lived in (Department of Education, 1944)

Prior to the advent of school counsellors, guidance was broadly influenced by ideas from the USA, and specifically influenced by the UK, especially by publications from the National Institute of Industrial Psychology, and Cyril Burt's work in psychology on standardised tests, eugenics, the "backward" child and juvenile delinquency (Burt, 1947, $1948,1950,1957)$. Subsequently, school guidance counselling in New Zealand derived probably more from American experiences, especially in the blending in the 1950s of several movements which together became known as "counseling psychology". These six strands were: the "vocational guidance" movement; psychometrics and testing; trait and factor psychological theories; motivational psychology; personality development theories; and psychotherapy. It was from these strands that initial guidance counsellor training courses gained their focus (Besley, 2000; Nicholson et al., 1964). Many of the initial developments in school counselling occurred from the exchange of ideas between the USA and New Zealand, for example through the Fulbright Travel Award scheme which began in 1949, and enabled an exchange of New Zealand and American university staff on short term appointments. American educationalists visiting here, such as Robert Havighurst and David Ausubel, were highly influential in their contribution to developmental psychology, which in turn influenced counselling theories. New Zealand educationalists (C. E. Beeby, Fred Aitken, Thomas Hunter, Ruth Trevor and Bertram Allen) visited the USA, bringing back new ideas (Small, 2000). ${ }^{4}$ However, general directions and lessons on policy, definition, training, selection, and ethics were imported from both UK and USA.

Due to an increase in the number of suspensions, expulsions and disciplinary problems in the 1950s, something needed to be done in 
secondary schools, but quite what was unclear. In Christchurch, three visiting teachers each worked "with a group of five or six primary and intermediate schools plus three or four secondary ones associated with them" (Winterbourn, 1974, p. 91). Some secondary principals, well aware that visiting teachers were overloaded, wanted someone to work specifically within their own schools, rather than in a cluster of schools. As a result, the pilot guidance counsellor scheme that was set up in 1959 was a competitive model that compared visiting teacher and guidance counsellor systems to decide which was the better way to proceed (Winterbourn, 1974).

The guidance counsellor system, making use of former careers advisors, was based on models seen in USA by the Chief Inspector of Post-Primary Schools (F. R. G. Aitken) who "believed that the time was ripe and the social climate suitable to try them out here" (p. 92). At the end of 1959, two visiting teachers were appointed to secondary schools in the Wellington area (Naenae and Onslow Colleges), and the first school guidance counsellors to Tauranga Boys' College (Maurice Pentecost) and Avonside Girls' High School, Christchurch (Jean Herbison). The experimental position of school guidance counsellor in 1959-60 was within a school (rather than peripatetic for a cluster of schools), combining "the functions of careers adviser, educational adviser and visiting teacher" and was partially or completely free from teaching to be "readily accessible and prepared to meet pupils frequently" (p. 93). Referrals were from classroom teachers and visiting teachers in contributing schools. Supervision was by Department of Education Inspectors (with no particular expertise in guidance) and by Psychological Service educational psychologists who provided a regular service to help guidance counsellors in their work with problem pupils. The effectiveness of the two systems was reviewed in 1962, with the Director of Education reporting to the Minister that the guidance counsellor scheme was better for large schools, while visiting teachers were suitable for groups of smaller schools (Winterbourn, 1974). So both types of guidance position continued.

Despite many requests from schools for one of the experimental positions, all but one was declined in anticipation of the 1962 Commission on Education, the Currie Report (Department of Education, 1962). This extra position was one visiting teacher to serve three Rotorua secondary schools, where there were "difficult learning and behaviour problems among the large Maori school population" (Winterbourn, 1974, p. 93). The Currie Report noted that the pilot guidance counsellor positions were "complex" and endorsed them as "cautious but enlightening experiments" (Department of Education, 1962, p. 668). It suggested that there needed to be "an almost full-time guidance or counselling officer" to provide counselling and to co-ordinate various helping services, in view of the fact that the careers advisor position was only part-time. The guidance counsellor would require a higher qualification than that which was expected of regular teachers, and so would need to be recompensed "not by a careers teacher's allowance but by the award of a position of responsibility" (Department of Education, 1962, p. 669). But until the school counsellor system was permanently established in the mid-1960s, vocational guidance officers and careers advisors within schools, and school psychologists from outside schools, were considered adequate to deal with students with social problems (Department of Education, 1962).

\section{Phase 2: 1964-1971: A Permanent Place for Guidance Counsellors in}

\section{Selected Schools}

The late 1960s witnessed the formal establishment of guidance counsellors in New Zealand secondary schools, but no mass appointments. In September 1964, the Director-General of Education recommended that guidance counsellors be appointed on a permanent basis, with the status of a Position of Responsibility $A^{5}$ in schools of over 500 students, whereby:

counsellors should replace careers advisors in single-sex schools and one of the two in co-educational schools. They should teach a minimum of two half-days a week or a maximum of three half-days a week. Training courses should be held annually for actual and prospective counsellors. Appointments in 1965 and 1966 should be limited to 12 each year or 24 for the two years, after which progress should be reviewed. The Director should have the final say in the selection of schools. (Winterbourn, 1974, p. 97)

However, Treasury vetoed this three times. Finally in May 1966, Cabinet approved a more limited service than that which either the Director-General or the Minister had approved two years earlier. Cabinet approved, subject to review, the appointment of up to 12 guidance counsellors to replace careers advisers in "schools with a large proportion of Maori, and to metropolitan schools with special problems" (p. 98). No additional positions were created. Rather, there was an extension of existing positions, in targeted areas as selected by the 
Department of Education, in new suburbs and/or low socio-economic areas with limited community resources and large numbers of Maori (e.g., Penrose, Rutherford and Otahuhu in Auckland). These targeted schools had students who were largely perceived as needing further disciplinary control, so the counsellor's role at this point was mostly as a control agent, encouraging difficult or underachieving students to change to fit in with societal expectations (Winterbourn, 1974).

Such a cautious introduction of guidance counselling reflected many issues: the influence of Treasury on policy and expenditure; issues of counsellor effectiveness and accountability; and probable suspicion over a job partly dealing with the psyche of young people in a nation where, even today, mental health services have considerable stigma attached (Mental Health Commission, 2000). Furthermore, there was strong lobbying from the powerful business community, fearful that jobs which suited its own ends, vocational guidance and careers advisors, would be diminished by the upstart, guidance counsellor position (Besley, 2000; Winterbourn, 1974).

In the 1960s, the Post-Primary Teachers' Association (PPTA) was influential in lobbying government, participating in Department of Education working parties to develop official education policy, and in discussing and formulating its own policies (PPTA Journal, 1960-80). A PPTA policy on school guidance counselling was established in 1968, and within three years probably the two most influential government policies followed - the Department of Education's Circular Memorandum $B, 69 / 31$ in 1969 incorporated all but three of PPTA's policy items and was followed by the Working Party Report (Department of Education, 1971). These followed the first official statements on school counselling in the Currie Report (Department of Education, 1962, pp. 655-674).

The initial model for guidance counselling in New Zealand combined careers and educational advice functions with the teaching and social work functions of a visiting teacher. Guidance counsellors were positioned to deal with the apparent rise in urban delinquency, operating as rescuer and trouble-shooter for students with social problems (Wadsworth, 1970; Winterbourn, 1974). The 1969 Department of Education policy detailed the place of the school guidance counsellor within the school and described the scope of the job. It shifted the earlier focus away from a rescuer/troubleshooter role and redefined the role, such that guidance counsellors were expected to provide educational, vocational and personal guidance to all students, and to teach 20-40 percent of the time (Miller et al., 1993).
The Department's recognition of three essential components of the counsellor's role systematised the policy first mooted by PPTA in 1968 and (presumably) prioritised as follows: educational guidance, vocational guidance, and personal counselling, with the first two having six and four sub-clauses respectively, the latter only one (Department of Education, 1969). Educational guidance involved classification, placement, testing and "tracking" of students. Such administrative functions were used to fit the child to the school system of the time, using ability-based streaming whereby course selection was largely dependent upon the abilities and aptitudes that students displayed in the testing process. In such a system it was not always clear in whose interests the counsellor was acting. Vocational guidance extended this ethos of administration, again helping to fit the child to the system this time into the world of work, using trait and factor theory. The use of testing procedures was not spelled out. The last component, focusing on the personal, and foreshadowing what has become one of the main functions of school counselling in the 1990s, was given only scant attention. Personal counselling was not to involve "intensive exploration and discussion of a pupil's motivations and personality difficulties, or to use those tests or other exploratory techniques for which prior training as a psychologist is a recognised pre-requisite" (Department of Education, 1969, p. v). That is, guidance counsellors were not to be de facto psychologists. In fact the issue of client safety was taken seriously. A counsellor was expected to take responsibility for ensuring that he/she "remains safely within the limits imposed by his role and by his personal competence, and that he refers pupils or parents requiring more extensive or intensive help to the appropriate specialist service" (Department of Education, 1969, p. v). The emphasis in the Department of Education circular (1969) on collegiality and relationships with other professionals involved in pastoral care foreshadowed the notion of a guidance network that was spelled out two years later in the Working Party Report (Department of Education, 1971).

From 1968, both PPTA and the Department of Education supported a policy of appointing trained teachers to be further trained in this specialist area (Besley, 2000). This was for several reasons. First, trained teachers have a clear knowledge and understanding of the structural components of the school system. Secondly, they have experience and expertise in dealing with adolescents. Thirdly, being a teacher enables a school counsellor to gain the trust and support of students, teachers 
and principals more effectively. Fourthly, guidance counsellors were intended to be the focal point of a school's guidance and counselling programme, but would share the responsibility with fellow teachers (Department of Education, 1969). After 1971, they usually led school guidance networks of pastoral care staff, so being a teacher provided acceptance and credibility. The importance, place, status and specialist post-graduate training of a guidance counsellor was indicated, first, in a specific staffing formula and secondly, in the allocation of a middle management position of responsibility (PR2 or two Management Units or higher depending on roll size). This remained until the 1996 staffing changes detailed later in this paper. The notion of the guidance counsellor as a "specialist teacher" was established in 1969; "a school guidance counsellor is a specialist teacher appointed to a position additional to a school's normal staffing establishment" (Department of Education, 1969, p. i) and has resurfaced in the Ministry of Education Performance Management Systems brochures from 1997 onwards.

These early policy documents detailed what guidance counsellors did and what they should be excluded from (including direct discipline, truancy, examinable teaching subjects). They indicated who the counsellor's clients were; how much time counsellors should take for different aspects of their work; what their status in the school was; and what their status and relationship should be to other staff members and outside agencies. What policies did not do was say, in a detailed way, "how" the job should be done, although they did mention in a very general way the sort of relationship that might exist between counsellor and client, and they also emphasised confidentiality. Official policy enabled some consistency in role definition and the place and status of guidance counsellors within state schools that were entitled to them. It also defined the extent and limits of school counselling, and thus its shape and professional identity. Although later policies have impacted on guidance counselling, none has been as extensive in providing a form of job description for guidance counsellors.

\section{Phase 3: 1971-1988: Guidance Networks and University Trained Counsellors}

From a small beginning in the 1960s, the numbers of guidance counsellors increased gradually through the 1970s and 1980s. While the Department of Education intended to introduce guidance counsellors to all secondary schools with over 400 students, this did not eventuate until 1988 (Department of Education, 1988).
One of the important policies in this phase was the comprehensive Guidance in Secondary Schools: Report of a Working Party, that not only surveyed all secondary schools, but also identified trends as it explored the relationship between careers and guidance counselling (Department of Education, 1971). In a large school it had become almost impossible for one person to deal with all three aspects of the job. It expected too much from too few, so the 1971 Working Party Report re-defined the guidance counsellor role, and assigned pastoral care roles and some educational and vocational guidance roles. However, only some of its 32 recommendations were adopted. These included: setting up guidance networks involving a wide range of staff to deal with pastoral care within a school (form teachers, deans, transition teachers); establishing guidance teachers, who combined guidance counselling and teaching in non-examinable subjects; adding to the role of guidance counsellor that of consultant to the rest of the staff regarding students; and requiring guidance counsellors to be responsible for educational, vocational and personal/social guidance (this being the suggested order of priority, with 60 percent of the time spent on educational and vocational counselling). They were also expected to act as agents for change.

A considerable volume of critique of the Working Party Report emerged in the next ten years, covering all manner of comment about the time, function and role of guidance counsellors, with an emphasis on accountability, and reflecting some of the problems and tensions within schools at the time. In the absence of any clear-cut job description, this literature focussed on role definition through surveys, and reports analysing how guidance counsellors actually spent their time: on the tasks and responsibilities of educational, vocational and personal counselling; in administration; in conducting socio-educational programmes; and in teaching (for a bibliography, see Manthei \& Miller, 1991, 1992)

Another significant move in this phase was the introduction of compulsory university training for guidance counsellors, fully funded by the Department of Education. This contributed significantly to the increased professionalisation of guidance counselling and alsoled to the establishment of a professional counselling organisation, the New Zealand Counselling and Guidance Association (NZCGA), set up to support school guidance counsellors and vocational guidance counsellors in 1974. In 1990, the NZCGA became the New Zealand Association of Counsellors (NZAC). NZAC's current membership is 
around 3000, about 400 of whom are school counsellors, and has, in the 21 st century, become the national professional body representing the counselling profession in New Zealand (see Besley, 2000, for a discussion of NZAC, ethics and professionalisation).

Prior to their being university-trained, guidance counsellors were trained under an induction system. Following the election of a Labour government, the first university course began at Canterbury University in 1973 with 11 appointees (Department of Education, 1973a). The Department of Education left it largely for John Small ${ }^{6}$ and other university educators to design the first course. Later that year, advertisements stipulated training on a university diploma course, enabling those selected to train at Massey University once its course was introduced in 1974 (Department of Education, 1973b, 1973c). Subsequently, Auckland, Waikato and Otago Universities ran counsellor education courses, but Otago's ceased in 1999, a victim of management restructuring decisions in the neoliberal environment. The first university counseling educators were hugely influential because of their position, personalities, expertise, experience and longevity ${ }^{7}$ in the role. Their academic interests and expertise influenced which theories predominated - mostly counselling psychology and the human potential movement. ${ }^{8}$ That they were all Pakeha males was a sign of the times and something that only started to change somewhat in the latter 20th century. In regular meetings between the Department of Education and university counsellor educators, "political footballs" over issues such as field changes, education requirements, student selection, and coordination across service providers and educators were contested, but universities continued to have autonomy over course structure and content. University counsellor educators played a large part in defining and shaping the identity of school counselling in New Zealand, especially until the mid-1990s when practitioners from the field and NZAC became increasingly influential.

After being seconded for state-funded education, guidance counsellors were bonded for an equivalent time to repay the state's investment - something of a mixed blessing for both school and counsellor. In about 1980, the Department of Education permitted schools with a roll of under 400 to appoint part-time guidance counsellors who would counsel for 0.6 and teach for the other 0.4 of their time allocation. Training was compulsory for them as it was for their counterparts who were working full-time. The issue of counselling education following appointment remains an issue today, albeit a diminishing one now that the supply of trained counsellors has increased tremendously, so much so that some job vacancies advertised in the Education Gazette since 1999 have asked for trained counsellors who are members of NZAC.

By the late 1980s there were both post-graduate diploma and Masters level courses in counselling, of varying nomenclature (Besley, 2000). Changes in university education in the 1980 s resulted from issues such as the selection of counsellors, the restricted training structure, and the control by state agencies of the process for allocating students (Hermansson, 1990). Canterbury University replaced the Diploma in Education (Guidance) in 1985 with a Masters degree and accompanying Certificate in Counselling; Massey University introduced field-based training which capitalised on the university's expertise in extra-mural education; Waikato University allowed appropriate non-school related counselling students to take its course; and Auckland and Otago universities developed courses that paralleled their existing educational psychology programmes (Hermansson, 1990). ${ }^{9}$ These changes did not represent a break with the Department of Education, but were an assertion of professional identity and leadership on the part of the university counselling educators in favour of more generic counselling education than that just related to schools. The result provided more choice for prospective counsellors and gave greater autonomy to counsellor education programmes, enabling their continued existence in an environment that heard threats from Treasury about limited funding for training counsellors (Webb, 1996). If Treasury withdrew funding for training school counsellors a more generic form of counsellor education could continue.

\section{Phase 4: 1989-1995: Guidance Counsellors in All Schools}

Despite a gradual increase in the number of secondary schools with guidance counsellors through the 1970s and 1980s, some deemed to be pilot schools had several counsellors and guidance teachers, but others had none, despite having quite large rolls (e.g., Auckland Grammar chose to appoint a sports director instead of a guidance counsellor). To remedy this situation, in 1988 The New Zealand Education Gazette issued a statement requiring all integrated and state secondary schools with a roll of over 400 to use their guidance time allowance to appoint a full-time, PR2, Guidance Counsellor from the start of 1989 (Department of Education, 1988). Schools with fewer than 200 students were allocated one half day of guidance network time. 
This period from 1989 to 1995 formed the high point in school counselling provision. The place and status of the school counsellor and guidance staffing provisions (with brief job outlines of personnel considered to be part of a guidance time allowance), were clearly spelt out in the Ministry of Education's RS40 annual roll return. The guidance time allowance comprised: a guidance network (e.g., deans, form teachers for pastoral care and personal guidance of students); a guidance counsellor - full-time, permanent teacher trained to perform guidance counsellor duties, including careers advice; a guidance teacher - part-time teaching, part-time careers and general guidance of students; and a careers adviser - providing educational and vocational guidance to students and parents in schools with fewer than two guidance counsellors. Guidance counsellor positions were pro-rated at different levels of responsibility depending on the school roll, as follows:

- $\quad$ over 200 , a 0.6 part-time position;

- over 400, a full-time counsellor;

- over 900, a full-time counsellor and a half-time guidance teacher;

- over 1200, two full-time counsellors;

- over 1400, two full-time counsellors and a half-time guidance teacher;

- over 1800, three full-time counsellors.

In the earlier phases, guidance counsellors had a remedial and social control function, reflecting the current psychological deficit theories of functioning. By 1979, although the Johnson Report (Department of Education, 1979) still emphasised the remedial/adjustive function, it pointed to a broad developmental function where "guidance should permeate every aspect of school activity and should consider the best interests of the total community, as well as the individuals in it" because it "promotes positive development in all these areas" (p. 25). In the late 1970 s and 1980s guidance counselling adopted a more liberal, humanist developmental approach that included the setting up of guidance networks, consulting with teachers in relation to students and becoming agents of change.

Once counselling was set up in schools, during the decades of the 1970s and 1980s, it slipped from being a regular and continued focus of government policy, becoming virtually ignored by the Department of Education and subsequently by the Ministry of Education. It became an invisible player. Even the Johnson Report, with its emphasis on "guidance", downplayed "counselling". Counselling seems to have become part of the status quo in schools, with its role and place largely unquestioned. What did happen though, in the 1980s, was the emergence of special funding for transition teachers and transition education, at a time of increased youth unemployment - a move formalised in 1985 in Skills for Young People (Marshall, 1987). With schooling becoming constructed in terms of preparing or fitting the young for the workforce, both the academic curriculum and youth themselves were blamed for not providing or for not having the "right" skills - a re-emergence of the deficit model. Young people were encouraged to remain or even return to school to gain skills and qualifications to fit workforce requirements, which in turn lowered the unemployment figures (Webb, 1990). While "transition policy statements, like funding, have abounded" (Webb, 1990, p. 42) guidance funding did not, and there was little guidance policy made until the staffing statement in the late 1980 s, then nothing more until the mid1990s when accountability and management issues came to the fore (Besley, 2000; Webb, 1990)

\section{Phase 5: 1996 to the Present: Neoliberalism, Deregulation, \\ Devolution and Decentralisation}

The paradigm change from Keynesian economic management and welfare-oriented interventionism in response to the 1930s Depression, through to neoliberal monetarism in the latter part of the 20th century, has taken place in much of the Western world (UK, USA, Australia, New Zealand). In New Zealand after 1984, what had been a comprehensive social democracy became a neoliberal state with an agenda that continued unabated under successive Labour and National governments, although a slight change began to occur with the 1999 Labour-led coalition. Neoliberalism ${ }^{10}$ has resulted in an anti-state and anti-bureaucracy attack on political and social institutions in what is referred to as contracting or rolling back the state or the "New Zealand Experiment" (Boston \& Dalziel, 1992; Boston, 1995; Kelsey, 1993, 1995). The neoliberal commitment to the free market involves, first, the claim that market efficiency provides a superior allocative mechanism for distributing scarce public resources (so a fiscal austerity programme designed to shrink the public sector prevails) and, secondly, that the market is a morally superior form of political economy. Yet, the effect in New Zealand has been one of increasing gaps between rich and poor, and the growth of poverty in what could hardly be argued as morally 
superior allocative results (Boston \& Dalziel, 1992). The competitive, possessive form of individualism that is often construed as "consumer sovereignty" - emphasising freedom over equality and individual freedoms over community freedoms - implies first a "freedom from" (especially from state interference), rather than "freedom to", and secondly, an acceptance of inequalities that are generated by the market (Peters \& Marshall, 1996). Clearly, such notions have implications not only for education, but also for school counselling as a profession and for the world that the counsellor's clients have to deal with.

Debate about accountability in New Zealand schools emerged during the 1980s around concerns about standards of achievement, curriculum development and content, levels of public and parental participation, and managerial responsibility. Under the political doctrine of neoliberalism there is nothing distinctive or special about education, which is a service, product, or commodity to be treated like any other, to be traded in the marketplace. As a result, education became subject to competition, commercialisation, contracting out, targeting services, and the promotion of self responsibility. Neoliberal governments in the late 1980s formulated responses to this debate in education that centred on a managerialist approach where competition is central. Emphasis was placed on the four "D's": Decentralisation, Devolution, Deregulation and Delegation (Boston et al., 1996; Peters, 1999). Whilst the late 1980s and early 1990s saw the focus on reforming the administration of schools with moves towards directly resourced, self-managing schools, and to concepts of consumer choice and competition in education (Ministry of Education, 1988a, 1988b; Peters, 1999), the impact on school counselling was initially positive, as exemplified by the 1988 Education Gazette notice on staffing. But the neoliberal managerialist ideology that had permeated various parts of New Zealand's public service sector gained momentum in the 1990s, and by 1995 school counselling came under subtle attack in the staffing formula (Ministry of Education, 1995). The attack was not about counselling practices, but a management issue about the place and status of counsellors in schools.

The 1996 Ministerial Reference Group (MRG) staffing changes removed the previous staffing formula (as described for 1992 in Phase 4) so that guidance networks and guidance counsellors no longer held prescribed positions, but were simply part of the global staffing entitlement. A global staffing entitlement has serious implications, hinting that counselling is no longer important, possibly no longer needed in secondary schools and so threatens the very place and existence of this specialist teacher and the requisite professional training. Since 1996 there has been no formal requirement for secondary schools to have a school counsellor on their staff; the counsellor's status is no longer specified at 2MU (Management Units) in secondary schools of over 400 students; the counsellor no longer has to be a trained teacher, and compulsory counsellor education is no longer mandatory, as the previous Department of Education required (and funded), since it no longer has a specific staffing entitlement. Yet there had been no critique of, or consultation over, guidance counselling by the Ministry.

However, a report was written about career guidance (The Lynch Report) that supported the MRG, and either deliberately or accidentally ignored all previous government policy and statements on guidance and counselling in the existing staffing formula (Ministry of Education, 1995). It implied that "guidance time" was primarily used for career guidance, offered no explanation of what was meant by "guidance", nor made reference at all to the personal counselling, or to the social education or preventative programmes that school counsellors actually provide. In fact, except in small schools, the guidance counsellor does not now undertake career guidance. This is usually provided by another person, who may not have any counselling training whatsoever. The selective nature of this report overly emphasised the very narrow focus of career guidance, but was patently incorrect in suggesting that this was the major component of the guidance counsellor's job. Furthermore, the Lynch Report was uncritical of, and actually endorsed, the recommendations by the MRG that the previous staffing formula be removed. By so doing, it supported the removal of guidance networks and guidance counsellors from holding prescribed positions in New Zealand secondary schools. From the late 1990s, school staffing ratios, including guidance counselling, are defined more by the annual government Budget statements than by the Ministry of Education policy.

Currently, there seems to be some ambivalence about the place of guidance counsellors in schools, and even a reluctance in recent official policies to formally designate the guidance counsellor as performing certain guidance and counselling functions. For example, the Education Act (1989) requires schools to offer guidance and counselling if students are subject to suspension proceedings, but a school counsellor is not specified to provide this, although in most schools this is one of their functions. Another example is contained in the Ministry of Education 
endorsement of the place and work of school counsellors in Young People at Risk of Suicide: A Guide for Schools (Beautrais et al., 1998), but its failure to state at the same time that schools must have a counsellor. Guidance counsellors finally became visible again in the official documentation on performance management systems in schools in 1997 and now need to meet relevant professional standards (Ministry of Education, 1997, 1999a, 1999b; see Besley, 2000b, for a discussion of performance management of school counsellors).

The neoliberal agenda that promoted devolution of power to schools and Boards of Trustees via the notion of self-management and direct resourcing (or "bulk funding") of teachers' salaries was part of a larger strategy that attacked traditional welfare policies and reliance on the state by promoting self-reliance. Within self-managing schools, the board of trustees and the principal, not the Ministry of Education, have the power to decide how to staff their schools and allocate management units. Direct resourcing was removed in 2000, but while and where it existed, it provided extra money and flexibility in its use. It could fund any combination of teaching or non-teaching staff (including more counselling staff), or provide new equipment. It could also pay staff more by allocating management units. Despite the MRG changes and their lack of a formal place in schools, counsellors were not made redundant, but there is no requirement for a school to replace them with a counsellor or some other equivalent if they leave (e.g., a social worker, youth worker, or psychologist), or to contract out counselling services. It is to be hoped that the current position whereby most secondary schools have continued to have a permanent, $2 \mathrm{MU}$ position for school counsellors, using trained teachers, indicates not simply inertia, but an awareness of the importance of counsellors remaining within the school structure to deal with students' problems, rather than being contracted from outside (Besley, 2000; Webb, 1996).

Guidance counsellors and guidance networks became an integral part (and in fact a core function), alongside curriculum and administration functions, of New Zealand secondary schools after the 1971 Working Party Report. But the official discourse about guidance and guidance counselling in terms of educational policy largely disappeared from view in the 1980s and early 1990s. Guidance became subsumed within the descriptions of the two other core functions in the National Education Goals (NEGs) and National Administration Guidelines (NAGs) (Ministry of Education, 1993). In being accountable to the state, all schools are audited/evaluated (i.e., "inspected") by the
Education Review Office (ERO) as to their fulfilment of the NEGs and NAGs, so schools need to have school counsellors who can clearly demonstrate that they have a major role in enabling them to adhere to these guidelines and achieve these goals (NZAC, 1997, 1998; Besley, 2000). ERO teams seem to identify guidance primarily in relation to barriers to learning and health and safety concerns. For example, to fulfill the latter (NAG 5), counsellors deal with issues such as sexual harassment, sexual abuse, bullying, violence, physical abuse, and suicidality. They promote safe, healthy behaviour through individual, group and sometimes family counselling, by organising itinerant services in-house such as running health clinics; by co-ordinating programmes such as "Peer Support", "Cool Schools" (peer mediation), "Safe Schools", and "Eliminating Violence". NZAC argues that guidance is pivotal to all of the NEGs and NAGs and so has written School Guidance Counselling Contributions to the National Education Goals and the National Administration Guidelines, and attached it as a four-page appendix to their 1998 policy, School Counselling (NZAC Newsletter, 1997, 18(2), 1998). To make this transparent, rather than leaving counselling to the vagaries of restructuring under neoliberal policies, this policy statement was sent to all NZAC members, schools, the PPTA and the Ministry of Education. It describes how counsellors can contribute to all of the NEGs and NAGs. Despite this, I would argue that counsellors clearly contribute more directly to some of these than to others, although individual job descriptions may alter which ones are emphasised in different schools. Such functions are far more extensive than the narrow interpretation of "guidance" suggested by the Lynch Report and implied by the removal of specified staffing for guidance counselling in the MRG.

\section{Endpoint 2001}

School counselling was introduced into New Zealand secondary schools over 40 years ago as a means of dealing with a large number of educational, vocational and personal problems that students were perceived to have. This decision relied on socio-political issues as much as educational ones, a situation which has not changed and which school counsellors and NZAC continue to have to deal with. Whilst the nature of the problems may have changed with changing socio-economic and educational contexts, barriers to student learning remain. Most secondary schools are very aware of the increased stress on adolescents as a result of cutbacks in welfare and community 
assistance in the 1990s, and recognise that trained counsellors who provide counselling for the development and well-being of youth are important specialist teachers to have within their schools. Furthermore, if the current high suspension and youth suicide statistics are considered as indicators of need, school counsellors continue to have a vital role to play (Beautrais et al., 1998). At present, in lieu of any clear statement assigning counsellors to schools, their positions have become particularly vulnerable to the whims and prejudices of principals and boards of trustees. In the 21st century, while guidance counselling has an even gender split that reflects an increased numbers of female appointments in the mid-1990s, there remains a predominance of Pakeha and a dearth of counsellors from other ethnicities (Manthei, $1998,1999)$. This remains a problem that NZAC is grappling with, and which schools need to address. Now, more than ever, they need to use accountability evaluation data to support and explain their role, in order to justify their continued existence in secondary schools. As a means of enabling schools to fulfil the national requirements set by the Ministry of Education, I believe that school counselling can clearly demonstrate that it has an important part to play in meeting the emotional and social needs of adolescents, a part that requires specialist training, skills, understanding and expertise.

Notes

1. At this time the Department of Education included the Child Welfare branch, which did not separate out to become part of the Department of Social Welfare until 1972. The Social Welfare Act, 1971, saw an amalgamation of the Department of Social Security and the Child Welfare Division of the Department of Education from 1/4/1972. It also introduced the statutory designation of "social worker" in the state services (Dalley, 1998).

2. See New Zealand Herald; Truth; The Dominion, Christchurch Press, June October, 1954

3. "Mental hygiene" was related to the now discredited eugenics movement and came to prominence during World War II. It has now been replaced by the term "mental health" as the eugenic connection has largely gone. Mental hygiene is partly about preventive medicine, public health, social engineering and social control, and is currently defined as: "the science of promoting mental health and preventing mental illness through the application of psychiatry and psychology"(The Columbia Encyclopedia, 5th ed., 1993). Mental hygiene has resulted in public education programmes about mental hygiene, reforms in institutional care, the establishment of child guidance clinics which apply a combination of psychiatry, psychology and social work, and social education programmes in schools.

4. Dr David Ausubel, developmental psychologist, University of Illinois, visited New Zealand in 1957, causing controversy for his criticism of disciplinary practices, schooling, race relations and general perceptions about New Zealand in his book The Fern and the Tiki (Small, 2000). Fred Aitken was Chief Inspector of Post-Primary Schools. Thomas Hunter, professor of mental and moral philosophy at Victoria University of Wellington, was acknowledged as the "father" of psychology in NZ, setting up the first experimental psychology laboratory in 1908. Ruth Trevor was a remedial reading specialist who had trained under Beeby. Bertram Allen was a school psychologist, trained by Winterbourn, who completed post-graduate studies at Colombia University and then returned to Christchurch (Small, 2000).

5. Position of responsibility A (PRA) was a first level management position in schools. Subsequently, most counsellors were assigned a middle management position (PR2) as head of the guidance department. The current terminology of Management Units (MU) has superseded the term PR.

6. Personal communication with Dr J. J. Small, 1993.

7. Russell Bernstone died of cancer in 1979. The rest of these founding educators either continued until retirement in the late 1980s or are still working in counsellor education (Everts, Hermansson, Manthei).

8. At University of Auckland: Hans Everts - counselling psychology; at University of Canterbury, John Small - clinical psychology, with emphasis on vocational assessment and Carl Rogers; Bob Manthei rehabilitation counselling; Bryan Tuck and Brian Keeling were former vocational guidance officers, who both developed expertise in career development, research methods, evaluation and testing; at Massey University, Alan Webster - Robert Carkhuff, a post-Rogerian humanist, Gary Hermansson-counselling; Ted Wadsworth (inaugurated course at University of Waikato) and Russell Bernstone (also Massey University) brought a more humanistic slant, the former having a social work background, the latter school teaching.

9. Personal communications with Dr J. Everts, counsellor educator at the University of Auckland from 1973 to the present time; Dr R. J. Manthei, counselling educator at the University of Canterbury from 1974 to the present time; Dr J.J.Small, coordinator of foundation course at University of Canterbury; J. Winslade, counsellor educa tor at University of Waikato.

10. Neoliberalism in Britain, USA and New Zealand has been largely shaped by the theories of Friedrich von Hayek (1944) which focussed on the 
problems of the planned socialist economy, where the absence of a pricing system prevented producers from knowing the true production costs (and other possibilities). Hayek warned about the political dangers of socialism and totalitarianism which he thought came directly from the planned nature of institutions in socialist economies. After World War II, Hayek was concerned that governments were too welfare-oriented. This in turn fettered the free market, consumed wealth and infringed the rights of individuals. In 1947 he set up the very influential, international organisation, Mont Pelerin Society, to restore classical liberalism, the "free'"society and its main institution, the free market (Peters, 1999). It included some prominent economists who subsequently established the "Chicago School" (Friedman, 1962) and with it, the main strands of American neo-liberalism - public choice theory (Tullock \& Buchanan, 1962), and human capital theory (Becker, 1964).

\section{References}

Alcorn, N. (1999). "To the fullest extent of his powers": C. E. Beeby's life in education. Wellington: Victoria University Press.

Besley, A. C. (2000). Self, identity, adolescence and the professionalisation of school counselling in New Zealand: a Foucauldian-inspired perspective. Unpublished PhD Thesis, University of Auckland.

Besley, A. C. (2002a). Social education and mental hygiene: Foucault, disciplinary technologies and the moral constitution of youth. Education Philosophy and Theory, 34(4) (forthcoming).

Besley, A. C. (2002b, September). The professionalisation of school counselling in New Zealand in the 20th century. Access (Special Issue), 21(2) (forthcoming).

Beautrais, A. L., Coggan, C. A., Fergusson, D. M., \& Rivers, L. (1998). Young people at risk of suicide: a guide for schools. Wellington: Ministry of Education \& National Advisory Committee on Health and Disability.

Boston, J., Martin, J., Pallot, J., \& Walsh, P. (1996). Public management: The New Zealand model. Auckland: Oxford University Press.

Boston, J., \& Dalziel, P. (Eds.). (1992). The decent society? Essays in response to National's economic and social policies. Auckland: Oxford University Press.

Boston, J. (Ed.). (1995). The State under contract. Wellington: Bridget Williams Books.
Bowlby, J. (1947). Forty-four juvenile thieves: Their characters and home-life. London: Baillière.

Bowlby, J. (1953). Child care and the growth of love. Abridged and edited by Margery Fry. Harmondsworth: Penguin Books.

Burt, C. L. (1947). Mental and Scholastic Tests (3rd ed.). London: Staples Press.

Burt, C. L. (1948). Intelligence and fertility: The effect of the differential birthrate on inborn mental characteristics. London: Eugenics Society.

Burt, C. L. (1950). The backward child (3rd ed.). London: University of London Press.

Burt, C. L. (1957). The young delinquent (4th ed.). London: University of London Press.

Cohen, S. (1980). Folk devils and moral panics: The creation of the mods and rockers (2nd ed.). New York: St. Martin's Press.

Dalley, B. (1998). Family matters: Child welfare in twentieth-century New Zealand. Auckland: Auckland University Press in association with Historical Branch, Department of Internal Affairs.

Department of Education. (1944). The post-primary school curriculum. Report of the committee appointed by the Minister of Education in November, 1942 (Thomas Report). Wellington: Government Printer.

Department of Education. (1962). Report of the Commission of Education in New Zealand (Currie Report). Wellington: Government Printer.

Department of Education. (1969). Circular Memorandum B, 69/3. Wellington.

Department of Education. (1971). Guidance in secondary schools: Report of a working party. Wellington: Government Printer.

Department of Education. (1973a). The New Zealand Education Gazette, $52(3), 405$.

Department of Education. (1973b). The New Zealand Education Gazette, $52(18), 49$.

Department of Education. (1973c). The New Zealand Education Gazette, $52(22), 569$.

Department of Education. (1977). Growing, sharing and learning: The Report of the Committee on Health and Social Education (Johnson Report). Wellington: Government Printer. 
Department of Education. (1988). The New Zealand Education Gazette, 67(22), 1027.

Foucault, M. (1984). Space, knowledge and power. In P. Rabinow (Ed.), The Foucault Reader (pp. 239-256). New York: Pantheon Books.

Foucault, M. (1988a). Technologies of the self. In L. H. Martin, H. Gutman, \& P. H. Hutton (Eds.), Technologies of the self. Amherst: University of Massachusetts Press.

Foucault, M. (1988b). The political technology of individuals. In L. H. Martin, H. Gutman, \& P. H. Hutton (Eds.), Technologies of the self. Amherst: University of Massachusetts Press.

Foucault, M. (1989). The return of morality. In Foucault Live (Interviews 1966-84) (pp. 317-331). Trans. J. Johnston, S. Lotringer (Ed.). Columbia University, NY: Semiotext(e).

Hall, S. \& Jefferson, T. (Eds.). (1976). Resistance through rituals: Youth subcultures in post-war Britain. London: Hutchinson.

Hebdige, D. (1979). Subculture: The meaning of style. London: Methuen.

Hermansson, G. L. (1990). It won't be long: Counselling and guidance poised for the nineties. In J. Small \& T. Ambrose (Eds.), Counselling and guidance towards the nineties (pp. 162-173). Massey University, Palmerston North: NZAC.

Kelsey, J. (1993). Rolling back the state: The privatisation of power in Aotearoa/New Zealand. Wellington: Bridget Williams Books.

Kelsey, J. (1995). The New Zealand experiment: A world model for structural adjustment? Auckland: Auckland University Press, in association with Bridget Williams Books.

McRobbie, A. (1991). Feminism and youth culture: from "Jackie" to "Just Seventeen". London: Macmillan.

Manning, A. (1958). The bodgie: A study in abnormal psychology. Wellington: Reed.

Manthei, R. J. (1998). Survey of school counsellors. NZAC Newsletter, 18(4), 17-21.

Manthei, R. J. (1999). School counselling in New Zealand. Part I: A profile of school counsellors and their work. Part II: Student problems and their use of outside agencies. New Zealand Journal of Counselling, 20(1), 24-46.
Manthei, R. J., \& Miller, J. H. (1991). New Zealand counselling, therapy and guidance-related literature, 1980-1989: A bibliography. New Zealand Journal of Counselling, 13(1), 34-38.

Manthei, R. J., \& Miller, J. H., (1992). Part 2: New Zealand counselling, therapy and guidance-related literature, 1980-1989 - Additional references. New Zealand Journal of Counselling, 14(1), 2-13.

Mental Health Commission. (2000). The discrimination times: A report on an investigation into news media (re)presentation of people with mental illness. Wellington: Mental Health Commission.

Miller, J. H., Manthei, R. J., \& Gilmore, A. (1993). School counsellors and guidance networks: Roles revisited. New Zealand Journal of Educational Studies, 28(2), 105-124.

Ministry of Education. (1988a). Administering for excellence: Effective administration in education (Picot Report). Wellington: Government Printer.

Ministry of Education. (1988b). Tomorrow's schools: The reform of educational administration in New Zealand. Wellington: Government Printer.

Ministry of Education. (1993, April). School charters and the revised national education guidelines. The New Zealand Education Gazette. Wellington: Learning Media.

Ministry of Education. (1995). Report of the career information and guidance review panel (Lynch Report). Wellington: Learning Media.

Ministry of Education. (1997). Performance Management Systems. No. 5: Specialist Teachers. Wellington: Ministry of Education.

Ministry of Education. (1999a). Professional standards: Criteria for quality teaching. Secondary school teachers and unit holders. Wellington: Ministry of Education.

Ministry of Education. (1999b). Teacher performance management: A resource for boards of trustees, principals and teachers. Wellington: Ministry of Education.

Molloy, M. (1993). Science, myth and the adolescent female: The Mazengarb Report, the Parker-Hulme trial and the Adoption Act of 1955. Women's Studies Journal, 9(1), 1-25.

New Zealand Association of Counsellors. (1997). School Counselling: The role of the guidance counsellor. Draft policy document. NZAC Newsletter,18(2), 20-22. 
New Zealand Association of Counsellors. (1998). School counselling, with Appendix School guidance counselling contributions to the National Education Goals and the National Administration Guidelines. Unpublished letter to boards of trustees and others.

Nicholson, K. D., McLay, L. A., \& Clarke, W. J. H. (1964). National course for guidance counsellors. Auckland: Ardmore teachers College.

Peters, M. A., \& Marshall, J. D. (1996). Individualism and community: Education and social policy in the postmodern condition. London: Falmer Press.

Peters, M. A. (1999). Neo-liberalism. In M. A. Peters \& P. Ghiraldelli (Jr.) (Eds.). Encyclopedia of Philosophy of Education.

$<$ http://www.educacao.pro.br>

Peters, M. A. (2001). Poststructuralism, Marxism, and Neoliberalism: Between theory and politics. Lanham, MD: Rowman \& Littlefield.

Report of the Special Committee on Moral Delinquency in Children and Adolescents. (Mazengarb Report). (1954). Wellington: Government Printer.

Shuker, R., Openshaw, R., \& Soler, J. (1990). Youth media and moral panic in New Zealand: From hooligans to video nasties. (Delta Research Monograph No. 11). Palmerston North: Massey University.

Small, J. J. (2000). Almost a century: Educational studies at the University of Canterbury 1904-1999. Christchurch: University of Canterbury.

Soler, J. (1988). Drifting towards moral chaos: The 1954 Mazengarb Report: A moral panic over juvenile delinquency. Unpublished MPhil thesis, University of Waikato, Hamilton.

Soler, J. (1989). That incredible document known as the Mazengarb Report. Sites, 19, 22-32.

Thompson, K. (1998). Moral panics. London \& New York: Routledge.

Wadsworth, E. J. (1970). The role of the school counsellor. New Zealand Social Worker, 6, 13-21.

Webb, S. (1990). Guidance and transition: Unwilling bedfellows or happy partners? In J. Small \& T. Ambrose (Eds.) Counselling and guidance towards the nineties (pp. 41-46)., Palmerston North: Massey University, New Zealand Association of Counsellors.

Webb, S. (1996). A brief outline of the history of school counselling and its training in New Zealand. NZAC Newsletter, 17(2), 20-22.
Webb, S. (1998). NZAC - Counting for something. NZAC Newsletter, 18(4), 11-16.

Winterbourn, R, (1974). Guidance services in New Zealand education. Wellington, New Zealand Council for Educational Research.

Wylie, P. (1942). Generation of vipers. New York: Rinehart.

Yska, R. (1993). All shook up: The flash bodgie and the rise of the New Zealand teenager in the fifties. Auckland: Penguin.

\section{The author}

Dr Tina Besley is currently Research Fellow in the Department of EducationalStudies at the University of Glasgow, Scotland, UK. She has degrees in counselling and education. Tina has been a secondary school teacher, LifeLine counsellor, and has spent 12 years as a school counsellor in three large urban secondary schools. During this time she was actively involved on NZAC branch and membership committees. She has published on narrative therapy, the work of Michel Foucault, and Maori sexuality as a bi-cultural component for the health curriculum. Her research interests include: youth issues, in particular notions of self and identity and contemporary problems; school counselling; educational policy; educational philosophy; and poststructuralism.

Email: C.Besley@educ.gla.ac.uk 